\title{
Improving Professional Church Staff Interpersonal Relationships: Transformational Perspective
}

Oladele Olubukola Olabode*

Faculty of Education, Nigerian Baptist Theological Seminary, Ogbomoso, Nigeria

DOI: $10.36348 /$ jaep.2020.v04i12.001

| Received: 15.11 .2020 | Accepted: 26.11 .2020 | Published: 07.12.2020

*Corresponding author: Oladele Olubukola Olabode

\section{Abstract}

Interpersonal relationships among professional church staff are an inescapable reality for all those working in Christian organizations, and improving such a relationship is the function of effective and efficient leadership. It is in the context of these relationships that both the church staff and the entire congregation find fulfillment in gathering for a worship experience. However, interpersonal relationships are both negative and positive with implications on the effectiveness of staff members at work, the congregation as well as the growth of the ministry. Leaders with this tendency must possess the appropriate skills for productive relationships among the staff members, be able to apply the skills appropriate for excellent and rewarding results, having an understanding of the complexity of human nature. An understanding of the concept of interpersonal relationships existing among church staff and improvement on the positive interpersonal relationship expected among church staff as well as its implications to attract the divinity from the transformational perspective is the thesis of this article.

Keywords: Professional Church Staff, Interpersonal Relationship, Transformation, Christian Organization Divinity.

Copyright $\odot \mathbf{2 0 2 0}$ The Author(s): This is an open-access article distributed under the terms of the Creative Commons Attribution 4.0 International License (CC BY-NC 4.0) which permits unrestricted use, distribution, and reproduction in any medium for non-commercial use provided the original author and source are credited.

\section{INTRODUCTION}

Every institution, including the church of God, is established and sustained by relationships. Every leadership is acquainted with the fact that relationship is a fundamental and intrinsic part of every being, which is distinct to our existence. The fact remains that outside the nuclear family is the engagement that provides for most people social and spiritual contexts as well as demonstrates in the daily experience that no individual is an island entirely to itself and that the purposes of collectivity transcend the purposes of an individual [1]. Every leader should acknowledge that human interactions are fundamental to lives, giving meaning to creation and for the understanding of our existence; hence leadership activities that focus unduly on the technical and bureaucratic elements of an organization would be devoid of meaning [2]. Moreover, Leaders should be cognizant of the leadership style and behavior in working within the church environment, as interpersonal relationships among staff members play an essential role in the sustainability of any organization [3].

However, the interaction could be both negative and positive yielding negative and positive interpersonal relationships respectively among staff members in an organization. Invariably, understandings of positive interpersonal connections are associated with better individual and work-related outcomes [4], thus promoting a united, loving, and refreshing community before God (Psalms 133:1-2). Besides, Church leadership demands knowledge, skills, and everything at its disposition to keep the mutual covenant, building, and improving on the interpersonal relationship among the church staff members and the church community at large [3]. The development and maintenance of this relationship among staff members will create an organizational belonging which is a fundamental human motivation, guiding both voluntary and involuntary behaviors, thoughts, and emotions [5]. It is opined that improving the interpersonal relationship among church staff from the transformative perspective will enhance harmony, progress, and growth in the community of faith, as we take a look at professional church staff.

\section{Professional Church Staff}

"And in the church, God has appointed first of all apostles, second prophets, third teachers, then workers of miracles, also those who have gifts of healing, those able to help others, those with gifts of administration, and those speaking with different tongues..." (1 Cor. 12:28). Staff is a group of people working for an organization, firm, institution, or church 
[6]. However, Professional church staff connotes human resources under high spiritual calling and is responsible for creating the kinds of environment in which people can flourish or shrink in a Christian organization [7].

Adetunji [6] presents Professional church staff members as called persons serving in the church in some capacities in three categories: First, the pastors, who are professional clergymen by calling and training, recognized by the church to fulfill the traditional role as administrators of the sacrament and declaration of the Word; there are others also called and professionally trained to perform specialized ministerial roles such as, educators, musicians, counselors, administrators, youth ministers, children's ministers, evangelism and mission ministers, senior adult ministers..., carrying out their duties in the church.

Last, are other Christians trained to perform functional roles in the church such as cooks, janitors, secretaries, receptionists; others are custodians, engineers, and parking space or parking lot workers [8]. In other words, professional church staff members are persons called under God in the universal Christian church by an organization to be its leaders; it could be ordained and un-ordained men and women with the shared responsibility of assisting and participating in a church assembly for worship, nurture, as well as dispersing works and service in the world [6].

\section{Concept of Interpersonal Relationship}

Devito [9] defines an interpersonal relationship as communication taking place between two persons who have established a relationship, who are in one way or the other connected; as business associates, doctors and patients, counselors and counselees, romantic partners, and so on, events that permeate our lives. Furthermore, Berschield [10] describes an interpersonal relationship as a strong, deep, or close association and acquaintance between two or more people that may range from a brief duration to a long enduring relationship, an association which could be based on love, inference, or solidarity. The context can vary from family or kinship, friendship, work, clubs, neighborhood, and places of worship.

Invariably, Adegoke [11] views the interpersonal relationship as a process of understanding human relationships with emphasis on social skills, self-analysis techniques of effective communication, and resolving interpersonal conflicts. Therefore, interpersonal relationship infers a process involving nonstop, interrelated thoughts, feelings, and behaviors of persons in a relationship or association in which empathy is respected, social skills, and active participation take place. Invariably, interpersonal relationships could be seen as an individual's subjective experience of repeated interaction or connection with another individual.

\section{Interpersonal Relationship among Professional Church Staff}

The church as a body of believers has to be guided, protected, and nourished to grow, develop, and reproduce itself within the world to fulfill its mission [12]. Meanwhile, God has also provided ways acceptable to fulfill this loving and caring-concern of the church, which is through the range of gifts He has given to the church: apostles, prophets, evangelists, pastors, and teachers; for equipping the saints for the ministry work, increase the body of Christ, until we all attain to the unity of the religion and also the knowledge of the son of God, to mature manhood, to the measure of the status of the fullness of Christ (Eph. $4: 11-13)$. It implies that the Lord has made provision of staff or workers of proven character among the church membership to manage every unit within the vineyard to accomplish the given assignment of the church. These professional staff members in church administration either paid or voluntary staff is those running the daily affairs of the church.

Church staff must understand the dynamics of the relationship that exists in the office setting to respect the various operational lines to avoid dissonance among staff members. These relationship lines are; the vertical relationship, the horizontal relationship, and the ministry relationship as briefly analyzed by Adedokun [8].

1. The Vertical Relationship: This emphasizes an individual's relationship with God, understanding, and treasuring one's connection with the God of the church. It provides nurture, wisdom, guidance, and grace for interacting with others.

2. The Horizontal relationship: This is an individual's interaction with other staff members and the congregation as a whole. This health of this relationship is the interest of the church as the staff as well as the congregation cannot be separated from this relationship. This must be treated with care and caution as it could lead to triumph as well as tragedy.

3. The Ministry Relationship: This addresses the interface between staff members as it relates to roles, responsibilities, and lines of reporting by an individual member of staff. It is an agreed general rule binding staff members across the board.

The church must begin to nurture, assess, correct, and build up these relationships so that the whole body will be strengthened and enhanced, as the leaders focus on the contradictions in interpersonal relationships which arise when two or more people of varying differences maintain a dialectics in a relationship such as:

i. Openness and Closeness: A situation in which both partners expect openness in their communication to be dependable and maintain a healthy relationship, and on the contrary, one of them desires privacy. 
ii. Certainty and Uncertainty: Certainty is a bonding factor in a relationship, with a promise kept to comfort partners in a relationship but on the contrary, predictability makes the relationship uncomfortable.

iii. Connectedness and Separateness: This is a natural desire to have a close and permanent bond in a relationship. However, a partner in the relationship may want to be alone, a thought pattern of too much staying together may result in the loss of an individual's identity [13].

However, it should be noted that the work of ministry belongs to the whole church, and the concept of church professional staff interpersonal relationship is the affirmation of the interrelatedness of the calling as Christians, for positive interpersonal relationship is the heart of what makes the church extraordinary 14], and every leader is encouraged to build environments of trust, respect, professionalism, caring, compassion, collaboration, teaming, advising, caring, and nurturing [15].

\section{Cultivation Church Professional Staff Interpersonal Relationship}

Interpersonal relationships among church staff are not merely the beginning, but the foundation of any effective church ministry endeavor [16] which needs to be cultivated. However, service in the church must be based on relationships of respect and absolute regard for one another, and therefore, church leadership should approach Christian stewardship and service through the same foundational concepts of modeling, encouraging, and demonstrating the importance of relationships and positive interactions. Church professional staff leadership should be good communicators and listeners who would provide both good and bad feedback, challenge the staff members, and insists that effective interaction should be the core purpose of the church's existence, which will set a vision for the future of the organization. Inculcating the consciousness of trust and respect, demonstration of a sense of humor, empathy, and compassion that will work for the betterment of the entire church community and the staff

Sorenson \& Machell [17] believes that the cultivation of a strong and effective relationship among church staff members should be initiated and exemplified by the church leadership, a practically oriented process of high accountability and responsibility to God and one another in the church community. Consequently, if the church community will be in harmony, enjoy the serenity of the presence and the warmth of the Holy Spirit, and then a trusting interpersonal relationship will be developed through the following process:

1. Have personal knowledge of every church staff by encouraging personal visitation to their offices, know individuals by names, give an invitation to our office for personal conversation, and encourage such among staff members toward the church members [18].

2. Create time for sincere and professional support to the church staff, and facilitating staff's growth through quality professional development, creating working teams, listening and showing care and concern for the staff's needs, recognizing and celebrating staff for outstanding work and accomplishments. Instill the same in the staff as well [19].

3. Build positive rapport with staff members thereby forming a partnership for church decision-making, being easily accessible and addressing concerns in a timely fashion, encourage attendance and full participation in church functions, making the church welcoming for family members with opportunities to volunteer [20].

4. Collaborating with all the units of the church and other departmental staff, respecting the departmental core values, keeping the church community updated on the events and successes of each unit, conducting regular assessments, and utilizing the valuable resources offered by experienced members of the church [21].

\section{Transformational Approach for Improving Professional Staff Relationship \\ The conception of the transformational} approach gears not only to change the existing system and achieving desired goals but also to encourage a strong relationship between leaders and followers in form of motivation and inspiration. Therefore, the following transformation dimensional approach could be employed to improve a strong and lasting interpersonal relationship among church professional staff members.

\section{Influence confidence and appreciation among staff members}

The church leadership should encourage the attitude of confidence and appreciation among staff members, which form the basis for acceptance and radical changes among church members. Members of staff are encouraged to honor, appreciate, trust, admire and identify with one another [22]. There is the need to imbibe the spirit of cooperation which will in turn harness the potentials of each member for the achievement of the church goals [23]. Staff members are influenced for collective take risking, consistency and demonstration of high standards of ethical and moral conduct, and being exemplary role models for the church members.

\section{Model attributes of respect, trust, and faith among staff members}

The Church leadership should model qualities of respect, trust, and faith in staff members and other associate leaders in the church. Staff members are to derive pleasure in interaction that builds respect, trust, and faith among colleagues, be willing to make 
personal sacrifices for others' benefit and reassurance of overcoming obstacles Action and inactions of staff members should build respect and trust in the followers, and in return justly rewarded with the church members' trust [24].

\section{Inspire staff members for excellent achievement}

The tendency will inform inspiration that is collectively motivated by the staff members that spurs the collective achievement of the vision of the church excellently. Staff members are unanimously optimistic about individual members' future and that of the church, as well as being enthusiastic about needs to be accomplished. The staff members are inspired to provide meaning and be courageous enough to collectively face work challenges [25]. This enhances a positively influential relational tendency among the staff members that are rubbing on the church members indirectly.

\section{Stimulation of staff members' endeavors for innovation and creativity \\ Church leadership instigates collective} activities among staff members for innovation and creativity, staff members are encouraged to brainstorm collectively and harness individual insights to solve both individual and personal problem. This tendency will inform intellectual relationships among staff members in problem-solving and task-orientated activity through mentoring and inter-personal communication [26].

\section{Encourage interpersonal consideration among staff members:}

Church leadership integrates the perception of paying attention to individual staff members to meet needs and assist each staff member to grow through personal challenges. Each staff member as a matter of responsibility is encouraged to spend substantial time with one another to give support to develop strength at the time challenge and rejoice in the time celebration. This approach will inform personal and collective thoughtfulness among staff members thereby strengthening interrelatedness and the bond of love among all [27].

\section{Conclusion}

The need to maintain and improve on a strong and lasting relationship among staff members of different backgrounds, orientations, spiritual upbringing, who are daily striving for perfection before a perfect, holy, and righteous God, called to serve in the church demands a holistic approach. With an understanding of the different types of relationships that should exist among professional church staff and its contradictions, this work utilized the transformational dimensional approach as a panacea to address the need for personal knowledge of every church staff, creating time for sincere and professionally support of church staff, building positive rapport with staff members to form a partnership for church decision-making, and collaborating with all the units of the church and other departmental supporting staff. Full compliance to influencing confidence and appreciation among staff members, modeling attributes of respect, trust, and faith among staff members, inspiring staff members for excellent achievement, stimulating staff members' endeavors for innovation and creativity as well as encouraging interpersonal consideration among staff members will present godly and improved interpersonal relationships among church staff serving the people of a righteous and Holy God.

\section{REFERENCE}

1. Jahoda, M. (1982). Employment and unemployment: A social-psychological analysis. Cambridge, UK: Cambridge University Press.

2. Jordan, P. J., \& Troth, S. (2011). Emotional intelligence and leader member exchange: The relationship with employee turnover intentions and job satisfaction: Leadership \& Organization Development Journal. 32(3).

3. Men, L. R., \& Stacks, D. W. (2013). Measuring the impact of leadership style and employee empowerment on perceived organizational reputation. Journal of Communication Management, 17, 171-192.

4. Heaphy, E. D., \& Dutton, J. E. (2008). Positive social interactions and the human body at work: Linking organizations and physiology. Academy of Management Review, 33, 137-162.

5. Baumeister, R. M., \& Leary, M. R. (1995). The need to belong: Desire for interpersonal attachments as a fundamental human motivation. Psychological Bulletin, 117, 497-529.

6. Adetunji, O. G. (2010). Leadership in Action: A Sourcebook on Church Administration for Students and Ministers. Ibadan: Baptist press.

7. Berkley, J. D. (2007). Leadership Handbook of management and Administration. Revised and Extended edition, Baker Publishing Group. Grand Rapids, Michigan.

8. Adedokun, S. A. (2019). Relationship in MultiStaff Ministry in Advanced Multi-staff Ministry, edited by Emiola Nihinlola and Folashde Oloyede. The Nigerian Baptist Theological seminary Ogbomoso, Oyo state. Baptist Press (Nig.) Limited, Ibadan.

9. Devito, J. A. (2004). The Interpersonal Communication Book (10th ed.). Boston: PearsonAlly \& Bacon.

10. Berschield, 1999. The Greening Relationship. Science American Psychologist 4, 54, (4) pp.260266.

11. Adegoke, A. A. (2011). Helping Professions in Africa. Ilorin: University Press.

12. Tidwel, C. A. (1996). The Education Ministry of the Church. Broadman and Holman Publishers, Nashville, TN. 
13. Saligman, M. (2011). Flourish: A Visionary New Understanding of Happiness and Well-Being. New York: Free Press.

14. Lagasse, E., Connors, H., Al-Dhalimy, M., Reitsma, M., Dohse, M., Osborne, L., ... \& Grompe, M. (2000). Purified hematopoietic stem cells can differentiate into hepatocytes in vivo. Nature medicine, 6(11), 1229-1234.

15. Rieg, S. A. (2007). Young children's perceptions of school administrators: Fostering positive relationships.

16. Shields, C. M. (2006). Creating spaces for valuebased conversations: The role of school leaders in the $21 \mathrm{st}$ century. International Studies in Educational Administration, 34(2), 62-81.

17. Sorenson, D., \& Machell, J. (1996). Quality schools through quality leadership. (Paper Presented at the Annual National Conference on Creating the Quality School, Oklahoma City, OK.

18. Avolio, B. J., Walumbwa, F. O., \& Weber, T. J. (2009). Leadership: Current theories, research, and future directions. Journal of Psychology, 60, 421449.

19. Arifah, A., \& Nurnida, I. (2016). The effect of transformational leadership style on the lecturers. International Journal of Science and Research, 5, 1328-1332.

20. Anvari, R., \& Atiyaye, D. M. (2014). Determinants of effective communication among undergraduate students. Journal of International Education Studies, 7(9), 112- 121.

21. Asfaw, A. M., Argaw, M. D., \& Bayissa, L. (2015). The impact of training and development On employee performance and effectiveness: A case study of District Five Administration Office, Bole Sub-City, Addis Ababa, Ethiopia. Journal of Human Resource and Sustainability Studies, 3, 188-202.

22. Nye, J. (2013). Transformational and Transactional President. Leadership, 10, 118-124.

23. Odumeru, J. A., \& Ogbonna, I. G. (2013). Transformational vs. Transactional leadership theories: Evidence in literature. International Review of Management and Business Research, 2, 355-361. Retrieved from http://www.irmbrjournal.com/

24. Lewis, S. (2013). How can I create a positive work environment during cutbacks? Strategic HR Review, 12(6).

25. Aboyassin, N., \& Abood, N. (2013). The effect of ineffective leadership on individual and organizational performance in Jordanian institutions. Competitiveness Review: An International Business Journal, 23, 68-84.

26. Anderson, K., \& Sherman, A. (2008). Reexamining the Reciprocity of Principal and Teacher Leadership: Distribute Leadership and the Search Transformational Teacher Leadership University of New Brunswick and University of Calgary, Canada.

27. Ahmad, F., Abbas, T., Latif, S., \& Rasheed, A. (2014). Impact of transformational leadership on employee motivation in telecommunication sector. Journal of Management Policies and Practices, 2(2), 11-25. 